\title{
PENDIDIKAN INKLUSI: PENERIMAAN SISWA TERHADAP PERILAKU SOSIAL DAN EMOSI ANAK BERKEBUTUHAN KHUSUS PADA SMP NEGERI 2 SEWON DAN SMP MUHAMMADIYAH 1 BAMBANGLIPURO DI KABUPATEN BANTUL
}

\author{
Reni Setyawati \\ Program Pasca Sarjana \\ Program Studi Magister Studi Islam \\ Universitas Muhammadiyah Yogyakarta \\ E-mail: r3ni.ajizaman@gmail.com
}

\begin{abstract}
Abstrak
Penelitian ini bertujuan untuk mengetahui proses pendidikan inklusif dalam kaitannya dengan penerimaan siswa pada perilaku sosial dan emosional siswa dengan kebutuhan khusus di sekolah. Penelitian ini menggunakan metode campuran. Subyek penelitian siswa kelas VII dan guru di SMP Negeri 2 Sewon dan SMP Muhammadiyah 1 Bambang Lipuro. Hasil penelitian penerimaan siswa pada perilaku sosial dan emosional siswa dengan kebutuhan khusus yang dibuktikan oleh saling pengertian, keterbukaan, pendampingan dan komunikasi teman sebaya, pengakuan kemampuan dan interaksi dengan siswa berkebutuhan khusus. Tanggapan siswa reguler, ditemukan bahwa mereka menerima secara positif perilaku sosial dan emosional siswa dengan kebutuhan khusus yang dibuktikan dengan komunikasi berkelanjutan yang baik; pengakuan bakat dan kemampuan dan interaksi dengan siswa dengan kebutuhan khusus di lingkungan sekolah. Ditemukan bahwa nilai Asymp Sig (2-tailed) adalah 0,402>0,05. Tidak ada perbedaan yang signifikan dalam penerimaan siswa reguler untuk siswa dengan kebutuhan khusus di SMP Negeri 2 Sewon dan SMP Muhammadiyah 1 Bambanglipuro.
\end{abstract}

Kata kunci: pendidikan inklusif, penerimaan siswa, perilaku sosial dan emosional

\begin{abstract}
This study aims to determine the process of inclusive education in relation to student acceptance of the social and emotional behavior of students with special needs in school. This study uses a mixed method. The research subjects were grade VII students and teachers at Sewon State Middle School and Muhammadiyah Middle School 1 Bambang Lipuro. The results of the research are student acceptance of the social and emotional behavior of students with special needs as evidenced by mutual understanding, openness, peer assistance and communication, recognition of abilities and interactions with students with special needs. The responses of regular students, it was found that they positively accepted the social and emotional behavior of students with special needs as evidenced by good ongoing communication; recognition of talents and abilities and interactions with students with special needs in the school environment. It was found that the Asymp Sig (2-tailed) value was 0.402>0.05. There was no significant difference in regular student admissions for students with special needs in Sewon 2 Public Middle School and Bambanglipuro 1 Muhammadiyah Middle School.
\end{abstract}

Keywords: inclusive education, student acceptance, social and emotional behavior

\section{Info Artikel}

Diterima September 2018, disetujui Oktober 2018, diterbitkan Desember 2018 


\section{PENDAHULUAN}

Proses

pengembangan pendidikan inklusi dengan berbagai perubahan yang ada tidak terlepas dari berbagai permasalahan maupun hambatan yang ada di lingkungan sekolah. Implikasi penyelenggaraan pendidikan inklusi bahwa semua anak tanpa terkecuali Anak berkebutuhan khusus dan dengan latar belakang disabilitas dan/atau kebutuhan khusus apapun dapat belajar di sekolah, ini belum mampu berjalan dengan baik, masih banyak anak-anak berkebutuhan khusus di sekolah yang mendapat diskriminalisasi baik dalam pergaulan maupun layanan pendidikan. Kurangnya sosialisasi informasi tentang keberadaaan anak berkebutuhan khusus menjadi salah satu penyebabnya.

Hal ini menjadi dasar bahwa anak berkebutuhan khusus memperoleh hak yang sama untuk mendapatkan pelayanan pendidikan. Salah satu kesepakatan Internasional yang mendorong terwujudnya sistem pendidikan inklusi adalah Conventional on the Right of Person with Disabilities and optional Protocol yang disahkan pada Maret 2007. Pada pasal 24 dalam konversi ini dijelaskan setiap negara berkewajiban untuk menyelenggarakan sistem pendidikan inklusi di setiap tingkatan pendidikan.

Siswa reguler yang di lingkungan sekolah yang berbasis negeri dan siswa reguler di lingkungan sekolah berbasis agama, dalam hal ini sekolah Yayasan Muhammadiyah.
Ketika siswa di sekolah Muhammadiyah dengan bekal nilai-nilai agama yang banyak.Diharapkan mampu lebih baik dalam menbangun silaturohmi, kerjasama dan menerima kondisi anak berkebutuhan khusus di sekolah. Pemahaman ini sesuai dengan ajaran Islam, bahwa setiap manusia diciptakan dengan sempurna dan tidak ada yang sia-sia.

\section{Pengertian Pendidikan Inklusi}

Pendidikan khusus meliputi tiga macam pelayanan yaitu pengajaran yang dirancang khusus, layanan terkait dan bantuan dan jasa pelengkap yang dapat disebut juga sebagai susunan luas atau berbagai bantuan yang memungkinkan siswa penyandang disabilitas untuk dapat berpartisipasi dalam pendidikan umum, kegiatan ekstrakulikuler, dan kegiatan sekolah lainnya sehingga mereka dapat dididik bersama dengan yang bukan penyandang disabilitas. I

Inklusi adalah praktek yang mendidik semua siswa, termasuk yang mengalami hambatan yang parah maupun majemuk, di sekolah-sekolah reguler yang biasanya dimasuki anakanak non berkebutuhan khusus. Pendidikan Inklusi menurut Ofsted, sebuah sekolah yang mempraktekkan pendidikan inklusi merupakan sekolah yang memperhatikan pengajaran dan pembelajaran, pencapaian, sikap dan kesejahteraan setiap anak. 


\section{Pengertian Anak Berkebutuhan Khusus}

Anak berkebutuhan khusus adalah anak yang mengalami keterbatasan atau keluarbiasaan, baik fisik, mental-intelektual, sosial, maupun emosional, yang berpengaruh secara signifikan dalam proses pertumbuhan atau perkembangannya dibandingkan dengan anak-anak lain yang seusia dengannya.

Pengertian Anak berkebutuhan khusus atau berkelaian pada dasarnya anak berkebutuhan khusus adalah anak yang mengalami penyimpangan intelektual, fisisk, sosial, atau emosional secara mencolok dari apa yang dianggap sebagai pertumbuhan dan perkembangan normal.

Secara umum anak berkebutuhan khusus dapat dibedakan berdasarkan faktor penyebabnya, yakni faktor dari dalam diri anak (internal) maupun dari luar diri anak (eksternal). Adapun batasan anak berkebutuhan khusus yaitu;

a. Anak disabilitas penglihatan

b. Anak disabilitas pendengaran

c. Anak disabilitas intelektual

d. Anak disabilitas fisik

e. Anak disabilitas sosial

f. Anak dengan gangguan pemusatan perhatian dan hiperaktivitas (GPPH) atau attention deficit and hyperactivity disorder (ADHD).

g. Anak dengan gangguan spektrum autisma atau autism spectrum disorders (ASD).

h. Anak dengan gangguan ganda adalah anak yang memiliki dua atau lebih gangguan sehingga diperlukan pendampingan, layanan, pendidikan khusus, dan alat bantu belajar.

i. Anak lamban belajar atau slow learner adalah anak yang memiliki potensi intelektual sedikit dibawah rata-rata.

j. Anak dengan kesulitan belajar khusus atau specific learning disabilities.

k. Anakdengan gangguan kemampuan komunikasi.

Anak dengan potensi kecerdasan dan/atau bakat istimewa adalah anak yang memiliki skor inteligensi yang tinggi (gifted), atau mereka yang unggul dalam bidang-bidang khusus (talented) seperti musik, seni, olah raga, dan kepemimpinan.

\section{Pengertian Penerimaan Diri}

Menurut Sheerer menambahkan seseorang yang dapat menerima dirinya adalah jika seseorang tersebut mempunyai kenyakinan akan kemampuannya untuk menghadapai kehidupan, mengangap bahwa dirinya berharga dan sederajat dengan orang lain, mampu bertanggung jawab terhadap perilakunya, mampu menerima pujian secara obyektif, dan tidak menyalahkan diri sendiri.

$\begin{array}{lrr}\text { Menurut } & \text { Hurlock, (1974) } \\ \text { mengemukana } & \text { beberapa ciri } \\ \text { penerimaan diri untuk dapat } \\ \text { membedakan antara orang yang } \\ \text { menerima keadaan dirinya yang telah } \\ \text { mengembangkan sikap penerimaan } \\ \text { terhadap dirinya dengan orang lain }\end{array}$


yang menolak keadaan dirinya, antara lain:

a. Memiliki harapan yang realistis terhadap keadaan dan menghargai dirinya.

b. Yakin akan standar-standar dan pengakuan terhadap dirinya tanpa terpaku pada pendapat orang lain.

c. Memiliki perhitungan akan terbatasan dirinya dan tidak melihat dirinya secara irasional.

d. Menyadari asset diri yang dimiliki dan merasa bebas untuk melakukan keinginanya. Menyadari kekurangan tanpa menyalahkan diri sendiri.

\section{Pengertian Perilaku Sosial}

Menurut Krech, Crutcfield, dan Ballachey, perilaku sosial seseorang, tampak dalam pola respon antar orang yang dinyatakan dengan hubungan timbal balik antar pribadi. Perilaku sosial adalah adalah aktifitas fisik dan psikis seseorang terhadap orang lain atau sebaliknya dalam rangka memenuhi diri atau orang lain yang sesuai dengan tuntutan sosial.

Menurut Arthur S. Rober menyatakan perilaku atau tingkah laku adalah sebuah istilah yang sangat umum mencakup tindakan, aktifitas, respon, reaksi, gerakan, proses, operasi-operasi dan sebagainya. Perilaku sosial merupakan segala tindakan yang tidak terlepas dari nilainilai sosial dalam masyarakat yang dilakukan dalam pergaulan seharihari.
Macam-macam perilaku sosial menurut Sarlito, dibagi menjadi tiga yaitu:

a. Perilaku Sosial (social behavior) Perilaku ini tumbuh dari orangorang yang ada di masa kecilnya mendapatkan cukup kepuasan akan kebutuhan inklusinya.

b. Perilaku yang kurang sosial (under social behavior)

Timbul jika kebutuhan akan inklusi kirang dipenuhi, misalnya sering tidak diacauhkan keluarga kecilnya.

c. Perilaku terlalu sosial (over social behavior)

Psikodinamikanya sama dengan perialku kurang sosial, yaitu disebabkan kurang inklusi. Orang yang terlalu sosial cenderung memamerkan dirinya berlebihlebihan (exhibitonistik).

\section{Pengertian Emosi}

Menurut Albin emosi adalah sebutan yang diberikan kepada perasaan tertentu mempengaruhi bagaimana seseorang berpikir mengenai perasaan itu, dan bagaimana ia bertindak. Emosi merujuk pada suatu perasaan dan pikiran yang khas, suatu keadaan biologis dan psikologis dan serangkaian kecenderungan untuk bertindak.Emosi pada dasarnya dorongan untuk bertindak.

Menurut J.P Du Preez, emosi adalah reaksi tubuh saat menghadapi situasi tertentu. Sifat dan intensitas emosi sangat berkaitan erat dengan aktifitas kognitif (berpikir) manusia 
sebagai hasil persepsi terhadap situasi yang dialami.

\section{METODE PENELITIAN}

Metode penelitian yang digunakan adalah metode kombinasi atau mix method, yaitu metode kualitatif dan metode kuantitatif.

\section{Teknik Pengumpulan Data}

1. Wawancara

2. Observasi

3. Studi Dokumentasi

4. Angket

\section{Teknik Analisis Data}

Menggunakan teknik analisis deskriptif dengan menghitung;

1. Persentase setiap item instrument angket

2. Melaksanakan Uji beda dengan analis analisis non parametrik dengan jenis Metode pengujian Mann-Whitney, dengan rumus $\mathrm{N} \geq$ 25 .

\section{HASIL DAN PEMBAHASAN}

Sebagai sekolah penyelengaraan pendidikan inklusi SMP Negeri 2 Sewon dan SMP Muhammadiyah 1 Bambanglipuro menerapkan prinsip bahwa semua peserta didik mempunyai hak memperoleh pendidikan.

Penerimaan Siswa Reguler Terhadap Perilaku Sosial Dan Emosis Anak Berkebutuhan Khusus

Berdasarkan hasil perhitungan persentase dari setiap aitem intrumen, maka dapat ditentukan indikator perbandingan dalam pelaksanaan pendidikan inklusi dalam penelitian ini di SMP Negeri 2 Sewon dan SMP Muhammadiyah 1 Bambanglipuro, meliputi ;

1. Informasi yang tepat mengenai anak berkebutuhan khusus

2. Proses kegiatan belajar mengajar di kelas

3. Kesiapan guru dalam pembelajaran di kelas

4. Penyediaan aksessibilitas dan sarana prasarana penunjang anak berkebutuhan khusus di sekolah.

Adapun indikator penerimaan siswa terhadap anak berkebutuhan khusus dalam penelitian ini terdiri atas;

1. Saling membantu, dengan kekhusus yang dimiliki maka tindakan saling membantu sebagi bentuk penerimaan yang nyata di antara siswa reguler dan anak berkebutuhan khusus.

2. Memahami dan keterbukaan

3. Pendampingan terhadap anak berkebutuhan khusus oleh siswa sebaya.

Adapun indikator perilaku sosial dan emosi anak berkebutuhan khusus dalam penelitian ini terdiri atas;

1. Komunikasi, ini di tunjukan dengan interaksi yang timbal balik antara siswa reguler dan anak berkebutuhan khusus di lingkungan sekolah.

2. Perasaan mengakui kemampuan anak berkebutuhan khusus, anak berkebutuhan khusus, dalam spesifikasinya maka tidak hanya 
terbatas atau kekurangan namun juga mencakup siswa yang mempunyai kelebihan yang tinggi.

3. Reaksi dan sikap siswa reguler terhadap anak berkebutuhan khusus.

Berdasarkan semua indikator, di atas maka penerimaan siswa reguler terhadap perilaku sosial dan emosi anak berkebutuhan khusus pada kedua sekolah menunjukan penilaian sikap yang tinggi.Siswa reguler menerimaan anak berkebutuhan khusus di lingkungan sekolah.

\section{Pelaksanaan Uji Beda Dengan Mengunakan Metode Analisis Mann-Withney}

Adapun hasil penelitian dengan $\mathrm{N} \geq 25$, maka dapat disimpulkan sebagai berikut;

1. Uji beda terhadap penerimaan siswa regular terhadap ABK pada SMPNegeri 2 Sewon dan SMP Muhammadiyah 1 Bambanglipuro. Test Statistics $^{\text {a }}$

\begin{tabular}{|c|c|}
\hline & $\begin{array}{c}\text { Penerimaan_Sisw } \\
\text { a }\end{array}$ \\
\hline Mann-Whitney U & 1825.500 \\
\hline Wilcoxon W & 3100.500 \\
\hline $\bar{Z}$ & -.83 \\
\hline $\begin{array}{l}\text { Asymp. Sig. (2- } \\
\text { tailed) }\end{array}$ & .40 \\
\hline
\end{tabular}

Dengan menggunakan uji beda

(Mann Whitney) dapat dilihat bahwa nilai Asymp Sig (2-tailed) sebesar $0.402>0.05$ dapat disimpulkan bahwa tidak ada perbedaan yang signifikan pada penerimaan siswa regular terhadap anak berkebutuhan khusus pada kedua sekolah.
2. Uji Beda Perilaku Sosial dan Emosi Anak Berkebutuhan Khusus Di Sekolah pada SMPNegeri 2 Sewon dan SMP Muhammadiyah 1 Bambanglipuro di Kabupaten Bantul.

Test Statistics ${ }^{\mathrm{a}}$

\begin{tabular}{|l|r|}
\hline & $\begin{array}{c}\text { Perilaku_So } \\
\text { sial }\end{array}$ \\
\hline Mann-Whitney U & 1568.000 \\
\hline Wilcoxon W & 2843.000 \\
\hline Z & -2.072 \\
\hline Asymp. Sig. (2-tailed) & .038 \\
\hline
\end{tabular}

a. Grouping Variable: Sekolah

Dengan menggunakan uji beda (Mann Whitney) dapat dilihat bahwa nilai Asymp Sig (2-tailed) sebesar $0.038<0.05$ dapat disimpulkan bahwa terdapat perbedaan yang signifikan pada Perilaku Sosial dan Emosi Anak Berkebutuhan Khusus Di Sekolah pada SMPNegeri 2 Sewon dan SMP Muhammadiyah 1 Bambanglipuro.

\section{KESIMPULAN}

1. Siswa reguler menerima anak berkebutuhan khusus di lingkungan sekolah. Ditandai dengan sikap saling membantu, memahami, terbuka, memberikan pendampingan tutur sebaya dan komunikasi, mengakui kemampuan dan interaksi reaksi siswa terhadap anak berkebutuhan khusus.

2. Tanggapan dari siswa reguler terhadap perilaku sosial dan emosi anak berkebutuhan khusus di sekolah adalah menerima positif, 
hal tersebut ditandai dengan komunikasi yang terus terjalan, perasaan mengakui kemampuan bakat dan interaksi siswa terhadap anak berkebutuhan khusus di lingkungan sekolah.

3. Berdasarkan uji beda (Mann Whitney) dapat dilihat bahwa nilai Asymp Sig (2-tailed) sebesar $0.402>0.05$ dapat disimpulkan bahwa tidak ada perbedaan yang signifikan pada penerimaan siswa regular terhadap perilaku sosial anak berkebutuhan khusus di sekolah SMP Negeri 2 Sewon dengan SMP Muhammadiyah 1 Bambanglipuro.

\section{SARAN}

1. Sekolah inklusi dalam implementasinya mempunyai konsekuensi bagi guru, untuk memahami keberadaan anak berkebutuhan khusus dan anak normal.

2. Dukungan dari semua pihak kaitanya dengan kebijakan Pendidikan Inklusi khususnya tentang penyediaan Guru Pendamping Khusus, yang masih dirasa kurang, baik secara jumlah mau kualitas waktu pembimbingan di sekolah Inklusi.

\section{DAFTAR PUSTAKA}

Bungin, Burhan. 2015. Metodologi Penelitian sosial dan Ekonomi: Format-Format Kuantitatif dan Kualitatif untuk Studi Sosiologi, Kebijakan Publik, Komunikasi, Manajemen, dan Pemasaran. Jakarta. Prenadamedia.
Deputi Bidang Perlindungan Anak. 2013. Panduan Penanganan Anak berkebutuhan khusus Bagi Pendamping (Orang Tua, Keluarga dan Masyarakat). Jakarta. Kementerian Pemberdayaan Perempuan dan Perlindungan Anak Republik Indonesia.

Friend, Marilyn, Bursuck, William. D. 2015. Menuju Pendidikan Inklusi Panduan Praktis untuk Mengajar. Yogyakarta: Pustaka Pelajar.

Geniofam. 2010. Mengasuh dan Mensukseskan Anak berkebutuhan khusus. Yogyakarta. Garailmu

Goleman, Daniel. (2004). Emitional Intelligence Kecerdasan Emosional Mengapa EQ Lebih Penting Daripada IQ). Jakata: PT Gramedia Pustaka Utama.

Hurlock, B. Elizabeth. 1995. Perkembangan Anak. Jakarta. Erlangga

James Julian M. 2008. The Accelerated Learning for Personality; Belajar Kepribadian, terjemahan. Tom Wahyu. Yogyakarta : Baca.

Kementerian

Pendidikan Nasional.2010. Modul Pelatihan Pendidikan Inklusi. Jakarta. Kemdiknas

Ormrod, J. E. (2008). Psikologi Pendidikan: Membantu Siswa Tumbuh d a n Berkembang (Edisi Keenam). Jakarta: Erlangga 
Praptiningrum.2010. Fenomena Penyelengaraan Pendidikan Inklusi bagi Anak Berkebutukan Khusus. Jurnal pendidikan Khusus. Vol.7.No.2.Nopember 2010. Yogyakarta. Fakultas Ilmu Pendidikan Jurusan Pendidikan Luar Biasa UNY.
Salim Utina, Sitriah. 2014. Pendidikan Anak Berkebutuhan Khusus. Jurnal Manajemen Pendidikan Islam. Volume 2, Nomor 1, Februari. Gorontalo: IAIN Sunan Amai 